Conference Paper

\title{
Transitional Space as Solution for Occupants Safety: Learning from the Past
}

\author{
Ami Arfianti ${ }^{*}$, Murni Rachmawati², Purwanita Setijanti² \\ ${ }^{1}$ Study Program of Architecture, Faculty of Architecture and Design, Universitas Pembangunan Nasional \\ "Veteran" Jawa Timur, Indonesia \\ ${ }^{2}$ Department of Architecture, Faculty of Civil, Planning and Geo Engineering, Institut Teknologi Sepuluh \\ Nopember, Surabaya, Indonesia
}

*Corresponding author:

E-mail:

amiarfianti.ar@upnjatim.ac.id

\begin{abstract}
This paper aims to show that for the safety of the occupants in today's architecture, we could learn from the spatial arrangement of the past architecture. In this paper, the adoption of the historiography method from historians was used to trace the genealogy of past architecture. Historiography is a method that is used to trace history back to the past to understand the past. By using historiography, the genealogy (line of a descendant) of vernacular Javanese building will be traced to find the transitional space in the spatial arrangement of the complex of housing. And then, the genealogy of vernacular Japanese buildings will be traced too, to find the transitional space in their spatial arrangement housing. To represent the European building, the genealogy of the Greek building will be used. Again, transitional space will be traced in their building. After that, the finding from these tracing will be compared to find the similarity and differences of the transition spaces. The result of this study showed that people from countries of samples did not design their building with open access to the spatial arrangement. There is always a transitional space from outside of the building to inside of the building. Because open access will make the occupants of the building prone to safety. Not only from tangible (physical) threats but also the intangible threats.
\end{abstract}

Keywords: Transitional space, safety, learning from the past

\section{Introduction}

Since December 2019, Corona Virus Disease had affected all the countries in the World. This pandemic had affected many aspects of life, including architecture. With the New Normal regulation, the lifestyle of many people changed. The spatial arrangement of the houses will not be the same, because our behavior changed. We become have more time in the home. We do work, school, religious activities, shopping even socializing from home. We should avoid or at least less more to entertain at home. But we cannot refuse every guest that comes to our house. What should we do to maintain our health safety concerning the spatial arrangement in our house? This paper trying to find some solution from the past to accommodate these changes 


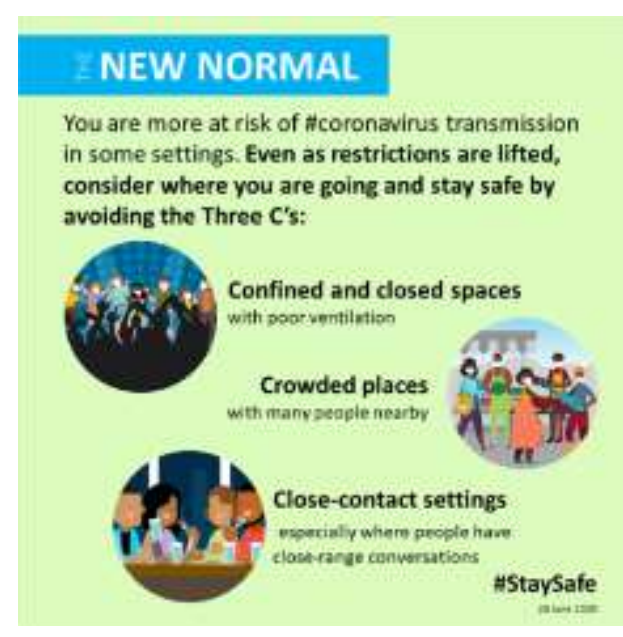

Figure 1. WHO new normal regulation

\section{Distancing}

In this trying time of Pandemic Corona Virus 19, the World Health Organization (WHO) suggests that we:

1. To keep the distance between one another at least 1 meter outside the building and further the better inside the building.

2. To always open the window so that the natural ventilation can increase when indoor. This suggests that we cannot use an active cooling system indoors but better to use a passive cooling system in the building.
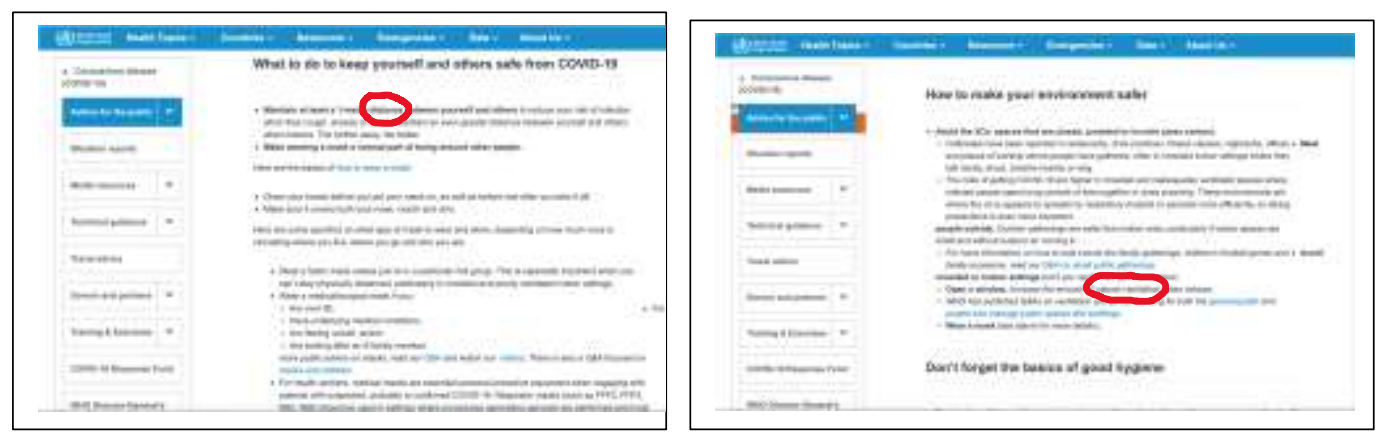

Figure 2. WHO guidelines: advice for public

There are still more guidelines from the WHO, but only these two that concern this paper. The focus of this paper will be on spatial distancing than the active cooling system because this paper will talk about the spatial arrangement. This is what makes me wonder if keeping the distance will change the spatial arrangement in the building. Could this space distance better the chance for keeping the safety of the occupants? We will try to find the answer from the spatial arrangement that happened in the past so that we can derive some knowledge.

\section{The spatial arrangement}

A spatial arrangement or usually called a building plan is the core of the building. This paper will discuss specifically domestic building or houses because we want the impact of this paper to spread widely not specifically among academists. In this paper, the cases were chosen according to the criteria: 
- Houses: domestically function buildings were appropriate to be the first criteria because houses were the human most needed element in life for security

- Vernacular: the building that last years or centuries were appropriate to be examined so that we can derive some knowledge from it. The span showed that there was some research (by trial and error) that had been done. By choosing the vernacular building we can learn from the past.

- Transition space/s: the space that exists between two things, inside-outside, closure-enclosure, nature-built in, etc.

- Courtyard: the criteria courtyard is chosen because analogous with the guideline from WHO, opens the window, and allows natural ventilation to work optimally. The presence of a courtyard will make the building thin, not massive, so the airflow between spaces (rooms) can be conditioned optimally.

\section{The transitional space}

Transitional space is "a place where boundaries dissolve a little and we stand there, on the threshold, getting ourselves ready to move across the limits of what we were into what we are to be" (Hertzberger, 2008). According to Green (2012), "Architecture defines a transitional space as a space located in-between outdoor and indoor environments acting as both buffer space and physical link". Transitional Space is the place between indoor and outdoor, between outside and inside, and acting as a buffer for threats that come from outside into inside. Or more eloquently to Park (2015) that explained the "In-between space' as an intermediate space between opposite elements such as whole and parts, inside and outside, open and close, central and decentral".

And Sou Fujimoto said to Knott (2014) in his interview for the Architecture Australia magazine, that "I like to find something in-between. Not only [between] nature and architecture but also [between] inside and outside. Every kind of definition has an in-between space".

The term of transitional space, analogous with the term in-between space is a place where people stand still for a second, to take a breath, to notice the surrounding, to cautiously step outside from the inside, and so on. This transitional space can be defined as a door, a threshold, a room with different level of the floor, a hall, a lobby, a yard, and so on as long as fulfill the criteria as transitional space. Because transitional space accommodated opposite elements, such as cool weather inside and hot weather outside, save world inside and dangerous world outside, we can say that there is always a level of cautiousness in this space. That is why this space content to be a buffer for the opposite elements. This is the keyword in this spatial arrangement. Making a buffer so that those opposite elements can be transferred between two different spaces.

\section{The tangible and intangible threats}

From the moment human beings needed shelter, the main reason for the need is physical threats like weather, wild animals, and enemies. The genealogy of human shelters can be traced from the cave, treehouses, tents, cabin, houses until the more elaborated houses like mansions and palaces. There are always physical threats from the beginning which is the tangible threats. We can saw it and try to eliminate it. And now we are dealing not only with tangible threats but also with intangible threats like viruses, bacteria, plaque and so on that can endanger our health. There are the more difficult threats that humanity has to deal. Because they are unseeable and when they come there was no indication that they were to come. After only contaminated that we can see the indications like fever, cough, flue, and so on. But with the guideline from WHO we still can maintain the precaution by distancing ourselves from the source. And we can distance our house by making transitional space from outside to the inside of our house to minimalize the threats. Transitional space becomes our buffer for safety not only from the tangible threats but also from the intangible threats. 


\section{Material and Methods}

The use of the historiography method in this paper because the past is what we are looking into. To see the history in the past to learn from them. There are two sections in this search to understand the past. First, to understand the past by searching from the literature of the intended cases and then by comparing the finding of the intended cases from several countries. The kinds of literature will be using spatial arrangement theories. The cases will be using the spatial arrangements in Javanese houses, the spatial arrangement in Japanese houses, and the spatial arrangement in Greek temples. In Greece, the use of the spatial arrangement of the temples, not the houses, because the source or role model of the houses in Greek using the pattern from the temple. First, we will trace from houses in the past about the spatial arrangement from different styles or countries. Second, we will find the differences and the similarity from the intended cases (Javanese houses, Japanese houses, and Greek houses). The finding will be discussed according to the safety regulation within the context of tangible and intangible threats.

\section{Results and Discussion}

\section{The transition space at Javanese Houses}
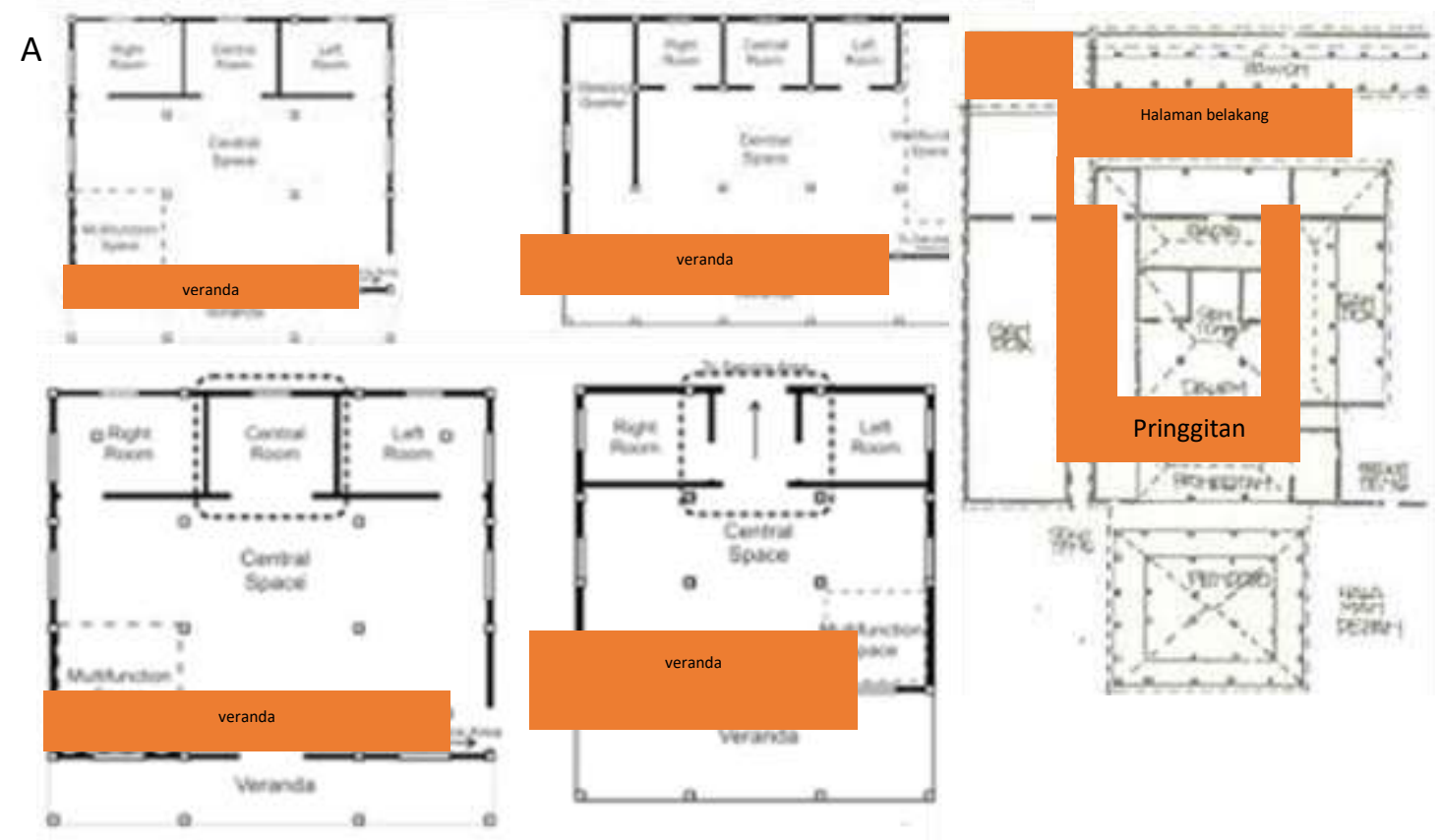

B
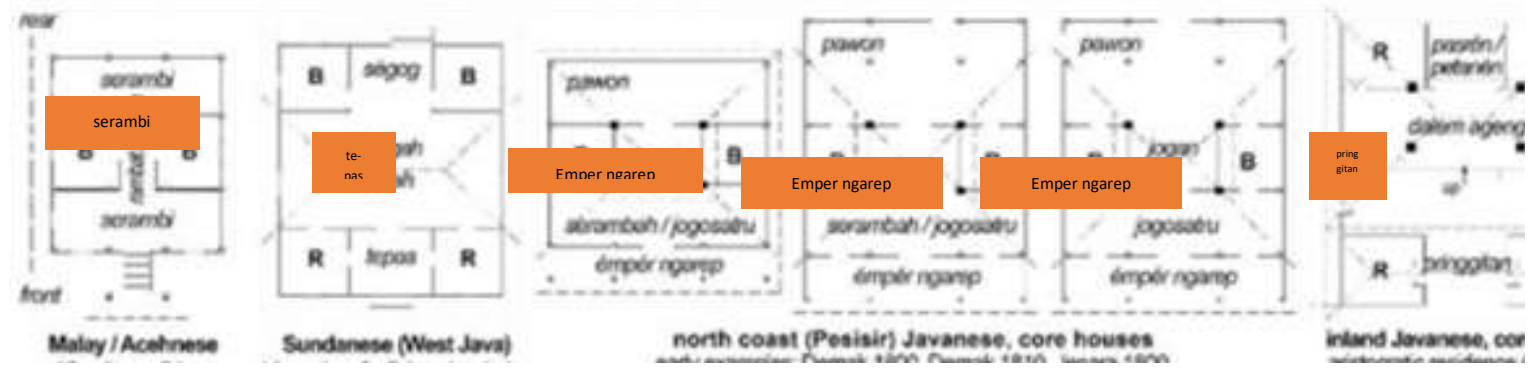

Figure 3. A. Different Javanese Vernacular Houses from the simple one (common people) to more elaborated or complex house. B. the variation of simple vernacular houses from Malay to coast and Inland Javanese houses. 
From the simple floor plan of Javanese Vernacular Houses to a more elaborated floor plan, we can see that they had applied a transitional space in their designs (the orange colored area). In the house for common people (from left to the right figures), the transitional space begun in front of the house, which is called emper (in Javanese) or veranda. Sometimes they added several stairs so that people who want to come into the house had to lower their head if they don't want to be tripped. This veranda comes with an open model, an unwalled secluded area, which is the very first layer of transition before people come into the house. After the veranda, the next buffer is the threshold. This threshold was made from woods with the lintel beam so low that people had to lower their heads if they want to pass. You cannot pass the head recklessly or you will be hit. You had got to move slowly. This is the second buffer or barrier for tangible threats. The more complex the house the more elaborated the layer of the transitional space. The royal houses had many separate function houses. And between each of the houses, there are transitional spaces. Like emper or veranda but more spacious. The buffer in this complex of houses will be the front yard, the pringgitan (the emper between buildings), the backyard, the emper between the main house (dalem) and gandok (pavilion) that houses the sons. There are many buffers in the royal house. Those buffers protected the habitats not only from tangible threats but also from intangible threats by distancing themselves from the guests or visitors.

\section{The transition space at Japanese Houses}

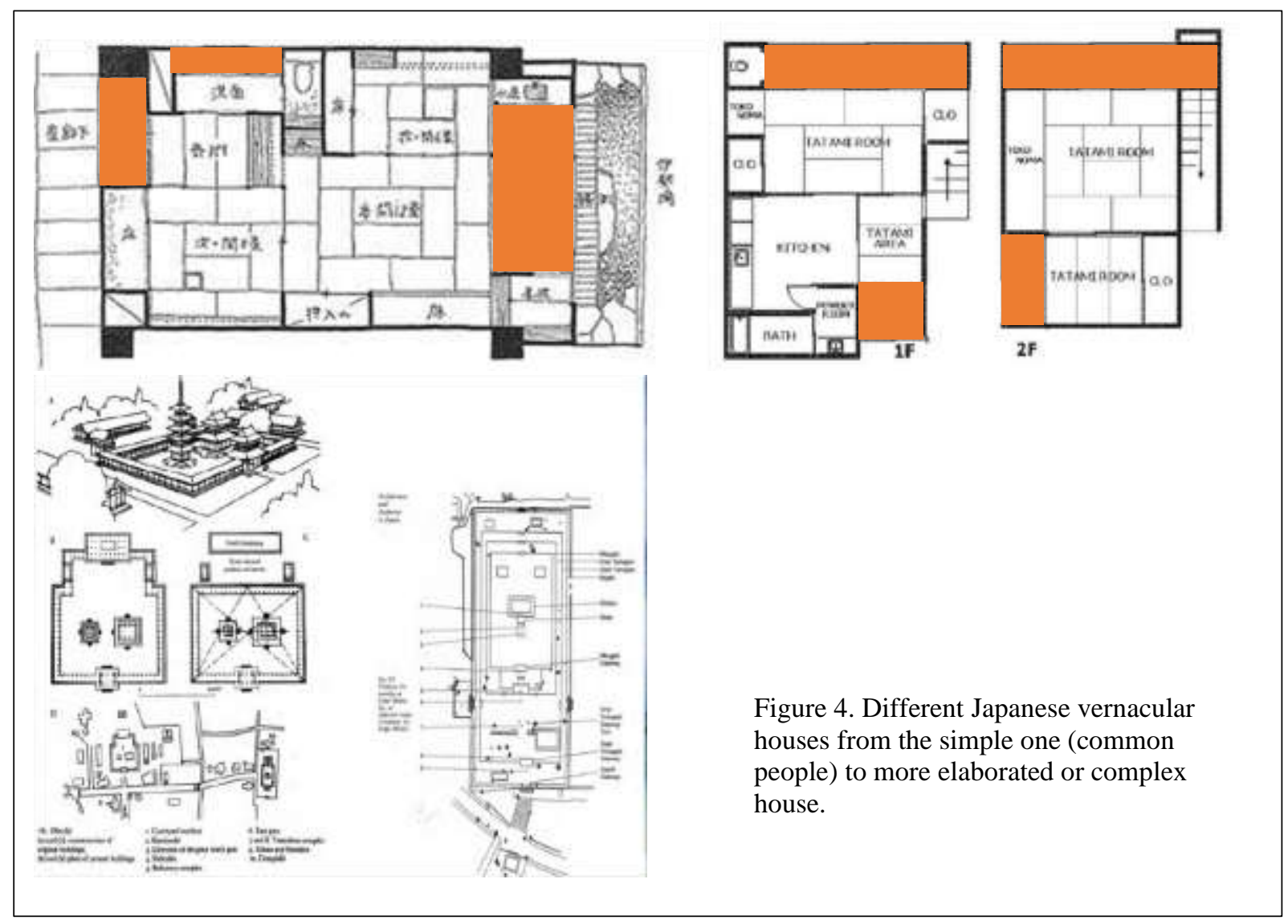

The diagram of Vernacular Japanese Houses showed that the houses also had transitional spaces. The more elaborated the floor plan the more layered the houses had (from left, clockwise). Because of their custom to take off the shoes, the floor plan of the house had some spaces for the purpose in front of the house. The first thing people do for entering the house is to take off the shoes and then barefooted or using sandals they entered the house. This is the layer of buffer in 
simple Vernacular Japanese Houses. In more complex houses (usually owned by the rich or royal family), the layer is more elaborated. So is the floor plan. The first buffer is the first gate (main gate) that connected immediately the house and the street (outside). The second layer is through the second gate to the front yard. The third layer from the front yard to the courtyard through the third gate. And inside the complex, the many buildings are separated either by the courtyard or by the inner yard and back yard. They connected the buildings by hallways. The arrangement of the spatial makes it difficult for the enemy to attack. And the multi-layered of buildings make people cannot make contact immediately or directly. Alas with this multi-layered spatial arrangement, the safety of the habitants is a guarantee from the tangible and intangible threats.

\section{The transition space at Greek Temple}

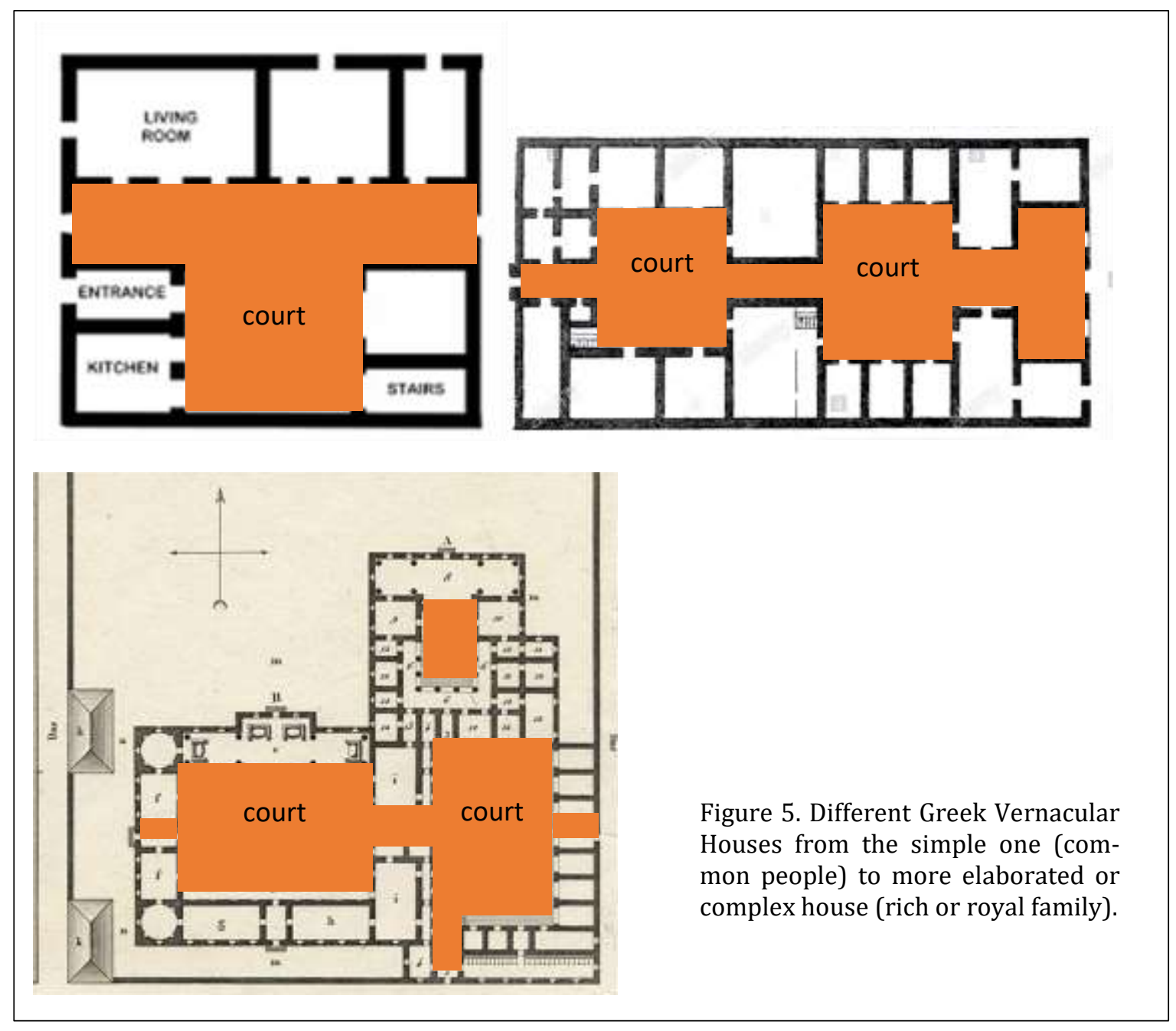

The diagram floor plan of Vernacular Greek houses had similarities from the simple houses belong to common people to complex houses belong to the rich or royal family. The houses always had a courtyard. The more complex the houses the more complex the courtyard, and the more layered. The arrangement allowed the inhabitant to have fresh air all the time, with the courtyard the size of almost half the house. This courtyard will allow optimal ventilation through the house but also the courtyard can make the inhabitant distancing or not directly contacted the guests or visitors. 


\section{The differences and the similarity}

Although the form of these transitional spaces can be various, from only a threshold, an emper (veranda), until more elaborated courtyard. The courtyard of the Javanese house differed from the courtyard of Japanese and Greek houses. The Javanese house's courtyard separated each building, making the layout of the house multi masses of buildings. Whilst the layout of Greek houses had a continuous courtyard from the outside to the inner of the buildings. The courtyard of Japanese houses more a mixture of Javanese houses and Greek houses. Every layer of Japanese houses was strengthened by the existent of gates. Every layer had a gate.

From the point of view of the floor plan, the safest house will be the Japanese houses. Because of the existence of the gates in every layer, making more difficult for threats to enter the building. The weakness of arrangement in Javanese houses was the openness of the transitional space. In the simple common people houses or the more complex houses. And the weakness of Greek houses was that the courtyard formed a continuous courtyard from one gate to the other gate. Although with the existent of the courtyard served the purpose of distancing and not directly contact the guests or visitors.

\section{Conclusion}

From the discussion and the result from comparing the three cases, we can conclude that:

1. Adding a courtyard to the floor plan of houses will make the inhabitants safer from tangible and intangible threats.

2. The more transitional space added to the floor plan the more buffered existed, making the habitats more safely inside the house.

3. The ideal form of the courtyard if every layer of transitional space (courtyard) had a barrier (gate).

\section{Acknowledgment}

The authors say thanks to UPN Jawa Timur and ITS Surabaya for supporting this research.

\section{References}

Hertzberger, H. (2008). Space and learning: Lessons in architecture 3, 010. Rotterdam

Green, M. (2012). So, what exactly is transitional space? changets.wordpress.com

Knott, S. (2014). Sou fujimoto: The spaces in between, architecture AU Magazine, 25 Sep 2014, www.architectureau.com

Park, H. (2015). A study on the meaning of in-between space in Sou Fujimoto and Bernard Tschumi's Architecture, Korean Institute of Interior Design Journal 24(6):87-95, DOI: 10.14774/JKIID.2015.24.6.087

The WHO Guideline for Corona Virus, www.WHO.int. 